IJMPB

11,2

Received 21 June 2017

Revised 28 November 2017

Accepted 29 November 2017

\section{Linking trust and collaboration in project teams to project management success}

\author{
Taryn Jane Bond-Barnard \\ Department of Engineering and Technology Management, University of Pretoria, \\ Pretoria, South Africa \\ Lizelle Fletcher \\ Department of Statistics, University of Pretoria, Pretoria, South Africa, and \\ Herman Steyn \\ Department of Engineering and Technology Management, University of Pretoria, \\ Pretoria, South Africa
}

\begin{abstract}
Purpose - The purpose of this paper is to emphasise the importance of high levels of trust and collaboration for increasing the likelihood of project management (PM) success. However, the link between these three constructs remains unclear.

Design/methodology/approach - In this study, the authors use structural equation modelling (SEM) based on the findings from an international survey of 151 project practitioners to demonstrate the significance of project team trust and collaboration for increasing the likelihood of PM success.

Findings - The results indicate that PM success becomes more likely as the degree of collaboration improves which, in turn, is influenced by an increase in the level of trust between team members. The two factors of PM success are project performance and knowledge integration and innovation. The six factors of the degree of collaboration that were studied are physical proximity, commitment, conflict, coordination, relationships and incentives. The three factors of the level of trust investigated are expectations, knowledge exchange and imported trust.

Practical implications - The results of the study are expected to provide insight for project practitioners to increase the likelihood of PM success by taking cognisance of the factors that influence collaboration and trust. The results of the study may also provide insight into teaching and learning in tertiary education, in terms of professionalism and integrity issues.

Originality/value - This paper presents a new perspective for investigating PM success. SEM techniques are used to determine the likelihood of PM success by promoting trust and collaboration in the project team. This unique approach highlights the "human factors" that influence perceived PM success which should benefit both researchers and practitioners.
\end{abstract}

Keywords Trust, Collaboration, Structural model, Project management success

Paper type Research paper

\section{Introduction}

The constituents of project success have been widely researched (Andersen $e$ t al., 2006; de Carvalho et al., 2015; Pinto and Slevin, 1988). The prevalent interest in project success is due to the increasing efforts (and resources) that companies are expending to implement project management (PM) (de Carvalho et al., 2015).

PM literature frequently associates project success with measures of cost, time and quality, also known as the "iron triangle" (Atkinson, 1999; Berssaneti and Carvalho, 2015).

International Journal of Managing Projects in Business Vol. 11 No. 2, 2018 pp. $432-457$

Emerald Publishing Limited 1753-8378

DOI 10.1108/IJMPB-06-2017-0068
(C) Taryn Jane Bond-Barnard, Lizelle Fletcher and Herman Steyn. Published by Emerald Publishing Limited. This article is published under the Creative Commons Attribution (CC BY 4.0) licence. Anyone may reproduce, distribute, translate and create derivative works of this article (for both commercial and non-commercial purposes), subject to full attribution to the original publication and authors. The full terms of this licence may be seen at $\mathrm{http} / / /$ creativecommons.org/licences/by/4.0/legalcode 
Even though these three measures are the most cited criteria, there is no consensus in the literature (Marzagao and Carvalho, 2016). Authors like De Wit (1988) argue that the best measure of project success is if the project meets its objectives, or by analysing cost and schedule margin variations (de Carvalho et al., 2015). Several authors state that the stakeholders' perception of project success is of primary importance especially for international development or social upliftment projects (Diallo and Thuillier, 2005; Ika et al., 2011; Yalegama et al., 2016). Shenhar and Dvir (2007) further argue that projects are part of the strategic management of the organisation, and, therefore, its success must be linked to its contribution to the short- and long-term view of the business. This is done by evaluating the project's efficiency, impact on the customer, impact on the team, business and direct success and preparation for the future. Most recently, PM sustainability in terms of a project's economic, social and environmental impact has been cited as being the most important factor (Martens and Carvalho, 2016). Several methods and techniques have been developed and are encapsulated in bodies of knowledge by institutes and professional PM associations that are aimed at improving PM outcomes (AXELOS, 2009; PMI, 2017).

Even though significant research has been conducted on project success factors, many projects continue to fail, as evidenced by several studies (Buchanan, Dai and Wells in de Carvalho et al., 2015; The Standish Group International, 2009; White and Fortune, 2002). Other empirical studies point out that PM failure may be due to the failure or a deficiency of the "human" project success factors (Belout and Gauvreau, 2004; Cooke-davies, 2002), amongst others, project collaboration (Aapaoja et al., 2013; Dietrich et al., 2010; Klimkeit, 2013; Michaels and Krisher in Mishra et al., 2015) and trust (Buvik and Rolfsen, 2015; Chiocchio et al., 2011a; Henderson et al., 2016; Jarvenpaa and Leidner, 1998; Kadefors, 2004; Kalkman and de Waard, 2016; Manu et al., 2015; Munns, 1995; Porter and Lilly, 1996; Rezvani et al., 2016; Smyth et al., 2010).

Several studies suggest a link between project trust, collaboration and PM success (Bond-Barnard et al., 2014; Buvik and Rolfsen, 2015; Holton, 2001; Manu et al., 2015). Many different approaches to modelling PM success have also been used (Belassi and Tukel, 1996; Fortune and White, 2006; Kendra and Taplin, 2004; Westerveld, 2003). However, there remains a gap in the literature with respect to understanding the constituents of, and a link between, trust, collaboration and PM success using structural equation modelling (SEM) techniques. SEM has however already been used in the construction industry to investigate the relationship between trust and partnering success (Wong and Cheung, 2005) and trust and project success (Weiping et al., 2016).

Buvik and Rolfsen (2015) and Henderson et al. (2016) suggest that project team trust and collaboration has a diverse and intertwining relationship with project success, which should be studied more thoroughly as both these singular case studies present inherent limitations to generalisability. Similarly, studies conducted by Walker and Lloyd-Walker (2015) and Ibrahim et al. (2015) both indicate that the top-ranked indicators that contribute towards successful team integration and performance are all relationship orientated. The aim of this study is to identify the factors that influence the constructs, level of trust, degree of collaboration and the likelihood of PM success, from literature. Second, a model indicating the theoretical relationship between trust, collaboration and PM success is proposed. Third, some empirical evidence towards validation of the model using novel SEM techniques is given to addressing the research gap. The methodological approach involves a cross-sectional, quantitative study.

This paper is divided into six sections. Section 2 summarises the constructs, their factors and the proposed model. The methodological approach is presented in Section 3. Model specification and refinements are discussed in Section 4; and Section 5 presents and discusses the results. Finally, Section 6 concludes and provides recommendations for future studies.
Trust and collaboration in project teams 
IJMPB

11,2

434

\section{Literature review}

Practitioners and researchers place a great deal of emphasis on achieving the objectives of the "iron triangle" of PM success (Agarwal and Rathod, 2006; Fortune and White, 2006; Turner and Cochrane, 1993) and focus less on the human-related aspect of projects which are woven into the very fabric of all the success factors that have been identified in literature (Cooke-davies, 2002). It is people who deliver projects, not processes and systems (Cooke-davies, 2002). A discussion of the human-related aspects of the PM success framework is important as it can be applied in most project contexts.

Human project success factors (in the context of the project team) have been investigated to some extent in literature. Studies have investigated:

- communication (Bond-Barnard et al., 2014; Diallo and Thuillier, 2005; Henderson et al., 2016; Ksenija and Skendrovic, 2010; Ochieng and Price, 2010; Turner and Müller, 2004);

- trust (Diallo and Thuillier, 2005; Gil et al., 2011; Henderson et al., 2016; Kadefors, 2004; Mumbi and McGill, 2008; Munns, 1995; Pinto et al., 2009; Smyth et al., 2010; Webber, 2008);

- collaboration (Cicmil and Marshall, 2005; Dietrich et al., 2010; Grabher, 2002; Holton, 2001; Vaaland, 2004);

- conflict (Chang and Yeh, 2014; Chiocchio et al, 2011a; Porter and Lilly, 1996; Stawnicza and Kurbel, 2012; Vaaland and Håkansson, 2003);

- commitment (Porter and Lilly, 1996);

- leadership (Aga et al., 2016; Turner and Müller, 2005);

- teamwork (Hoegl and Gemuenden, 2001);

- knowledge integration capability (Dietrich et al., 2010; Todorović et al., 2015); and

- personality and work motivation (Garhoud and Bredillet, 2016) as project success factors.

Most empirical studies on the above-mentioned human project success factors have been investigated in relative isolation from the other factors. This study focusses on the success factors of trust and collaboration. The interaction between trust and collaboration has received some attention in literature (Chiocchio et al., 2011b; Holton, 2001; Kalkman and de Waard, 2016). However, the relationship between the level of trust and degree of collaboration, and the contribution that these two constructs make to PM success, is still unclear in literature. The objective of this study is to investigate this link, so that both academics and practitioners can understand the complex dynamics between these factors better.

Linkages between project trust, collaboration and PM success have been purported (Buvik and Rolfsen, 2015; Holton, 2001; Manu et al., 2015). Two Australian studies, which were based on two different surveys of 57 and 50 alliancing subject matter experts, respectively, resulted in the development of models and a taxonomy that places collaboration as pivotal in building trust for effective information and knowledge sharing (Davies et al, 2016; Walker and Lloyd-Walker, 2015). In contrast, Buvik and Rolfsen (2015) and Daspit et al. (2013) found that cross-functional teams are dependent on the degree of trust between them to engage in collaborative interaction, as trust was identified as an important component of teamwork (Webber, 2008). Trust is recognised as a key factor contributing to project success (Wong et al. in Buvik and Tvedt, 2017). Handy (1995) found that the ability to work collaboratively is recognised as a core competency of a learning organisation or team, but that trust determines the dynamic of this collaboration. 
Collaborative learning as the basis for effective organisational team building requires a level of personal familiarity, intimacy and trust (Holton, 2001). In the construction industry, the sentiment is the same, a trust-based collaborative environment is required to facilitate high levels of information sharing and to secure commitments of the supply chain from the very early stages of a project (Manu et al., 2015). However, Manu et al. (2015) point out that significant research attention is still required on how to achieve trust-based collaboration in the construction supply chain. As literature offers stronger support for trust determining the degree of collaboration, this is also the direction of the relationship proposed in the model (Figure 1).

Müller (2003) established that communication improves project member collaboration and trust. Similarly, Bond-Barnard et al. (2014) found theoretical support for the proposition that, based on a foundation of quality communication, project trust and collaboration influence PM success. The authors acknowledge that quality communication is required for trust and collaboration in the project to thrive. However, this paper does not investigate the influence of

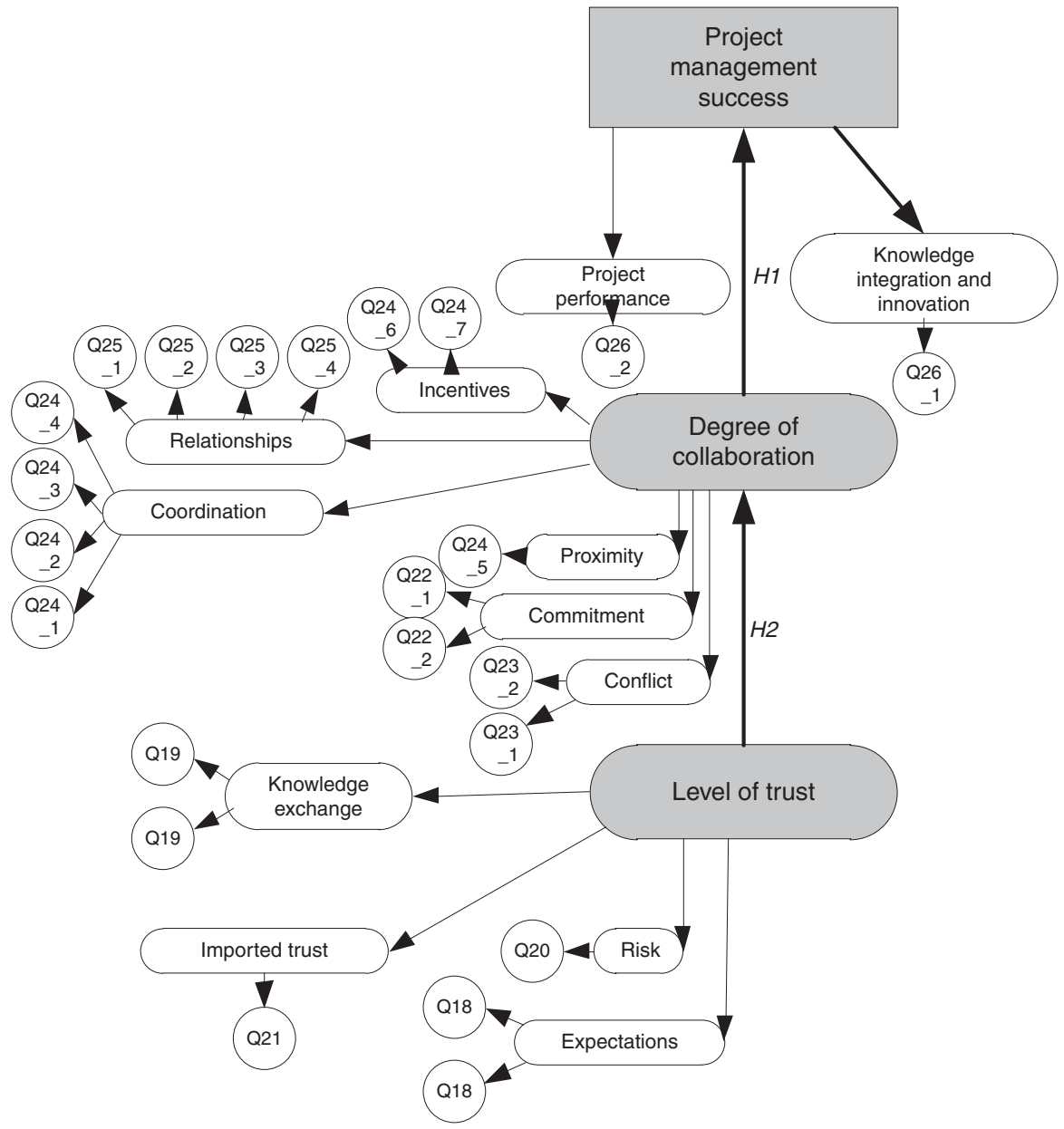

Trust and collaboration in project teams

Note: Symbols in circles indicate numbers of items in the survey questionnaire

Figure 1.

Hypothetical model for the relationship between level of trust, degree of collaboration and project management success 
IJMPB

11,2

436

communication as a success factor in much detail as the focus in this paper is on the relationship between (and factors influencing) trust, collaboration and PM success. Based on the fact that literature purports and that these human project success factors are actually constructs, a conceptual diagram of the structural model is presented in Figure 1 depicting the link between trust, collaboration and PM success based on literature, and the various factors/ variables influencing each construct. The arrow represents the direction of proposed influences in the structural model. The corresponding hypotheses are as follows:

\section{H1. PM success becomes more likely as the degree of collaboration increases.}

H2. The degree of collaboration increases as the level of trust in the project increases.

The intent of this paper is to measure the perceptions of clients, project leaders, team members and other stakeholders to determine which factors influence the level of trust and degree of collaboration by using confirmatory factor analysis (CFA) and SEM. The literature used to identify the factors for each construct are briefly discussed below, and Table AI provides more information as to how these factors were measured.

\subsection{Level of trust construct}

Trust can be defined as a function of the predictability and expectations of others' behaviours or a belief in others' competencies, which affects performance through activation of cooperation (Tyler, 2003) or other collaborative processes (Chiocchio et al., 2011a). When there is trust, people ask for help, speak openly and honestly, take risks, accept new challenges and carry out their activities with less anxiety and stress (Carvalho, 2008; Fox, 2001). Following a comprehensive literature review, it was decided to only focus on the following factors that influence trust, namely, the degree of knowledge exchange, dealing with uncertainty (risk) and meeting team members' expectations.

2.1.1 Knowledge exchange factor. Knowledge exchange is the push and pull found in the multiple, directional movement of data, information and knowledge between individuals and groups for mutual benefit (Levesque, 2005). Trust between the project team and the stakeholders or between any two or more stakeholders/team members is earned by doing what one says one will do on a continued, repeated basis. Trust develops from repeatedly receiving and sending project information across various formal and informal channels of communication which infers a level of reliability in the modality as well (Lesko and Hollingsworth, 2010).

For initial knowledge exchange to take place, some trust must exist between the team members so that information can flow along the agreed upon and appropriate lines of communication (Lesko and Hollingsworth, 2010). For this reason, Daim et al. (2012) state that it is important that the project manager promotes knowledge exchange by leading by example. He can do so by importing trust in the team or at the inception of the project through team member introductions that are positive and explain an individual's role and importance to the team. Knowledge exchange is a process that builds trust between the individuals or groups that are exchanging knowledge. In so doing, the level of trust in the project and in project relationships continues to grow.

2.1.2 Imported trust factor. "Swift trust" according to Daim et al. (2012), refers to the situation whereby members of a global virtual team (GVT) import trust from other familiar settings. Members initially employ category-driven information processing in forming stereotypical impressions of others. Thereafter, trust is maintained by a high level of action within the teams. High levels of action promote members' confidence that the team is able to manage uncertainties, risk and vulnerabilities. This type of trust is different than the traditional concepts of trust, since swift trust imports trust instead of developing trust over time via interpersonal relationships. As a result, Daim et al. (2012) state that maximum amount of "swift trust" is usually achieved at the project's inception. 
In contrast, Meyerson et al. (1996) state that swift trust is category-driven trust, between highly specialised professionals where the actors deal with one another more as roles than as individuals. Expectations, consequently, are more standardised and stable and defined more in terms of tasks than personalities: "We trust engineers because we trust engineering and believe that engineers are trained to apply valid principles of engineering" (Dawes in Meyerson et al., 1996).

Literature supports Meyerson et al.'s (1996) definition of swift trust (Dietz and Hartog, 2006; Grabher, 2002; Mumbi and McGill, 2008; Mumbi, 2007). For this reason, it is proposed that the trust that Daim et al. (2012) refer to above should actually be defined as "imported trust". Imported trust stems from team members introducing trust into a new project based on previous interactions. Imported trust differs from swift trust in that swift trust is a category-driven trust where actors have usually not met each other before but decide to trust one another based on the other actor's specialised role and existing competencies which are required to achieve the objectives of the project. Imported trust as defined by Daim et al. (2012) will be investigated in this paper. Specifically, its influence on the level of trust experienced by project team members. It is proposed that imported trust influences the level of trust in the project team if some (or all) the team members have previously interacted with each other, worked together or had a personal relationship.

2.1.3 Expectations factor. A factor in promoting trust and cooperation is the anticipation of future association (Daim et al., 2012). Trust between project stakeholders is earned by doing what one says one will do on a continued, repeated basis (Lesko and Hollingsworth, 2010). The realisation of expectations is important for the development of trust (Chiocchio et al., 2011a; Tyler, 2003). For example, broken promises on likely availability of design information is an important issue in the construction industry which leads to the breakdown of trust (Lesko and Hollingsworth, 2010; Rounce, 1998). This is because trust between project stakeholders is earned by doing what one says one will do on a continued, repeated basis (Lesko and Hollingsworth, 2010).

2.1.4 Risk factor. Risk is an uncertain event or condition that, if it occurs, may have a positive or negative effect on a project's deliverables (PMI, 2017). As the relationship between risk and trust is reciprocal, an acceptable degree of risk is responsible for an increase in the level of trust in a project. In the literature, one of the major reasons for the failure of GVT is related to building trust. Trust is crucial in any GVT as it allows people to engage in risk-associated activities that they cannot control or monitor (Daim et al., 2012). Therefore, risk can either positively or negatively influence the level of trust in a project team.

\subsection{Degree of collaboration construct}

Collaboration and cooperation are interchangeable terms which are defined as a recursive process where people or organisations work together in an intersection of common goals by sharing knowledge, learning and building consensus (Dietrich et al., 2010). Collaboration can occur between individuals, between organisations or between an organisation and its customers. Only interpersonal collaboration is considered here. To better understand how one can promote interpersonal collaboration in a project team, it is important that one is aware of the influence that various factors have on the degree of collaboration (Dodgson, Hoegl et al. in Dietrich et al., 2010; Jap, 1999; Mohr and Spekman, 1994).

According to Tyler (2003), trust affects performance through activation of cooperation or other collaborative processes. Trusting teams enhance cooperative and collaborative processes, which assist them to better manage the interdependencies among their respective areas of expertise. In addition, the interplay of situation-appropriate teamwork, communication, synchronicity and coordination has also been found to increase
Trust and collaboration in project teams 
IJMPB

11,2

438

collaboration in the project which is a factor of team performance (Chiocchio et al., 2011a; Kozlowski and Bell, 2003; LePine et al., 2008). High-quality collaboration in projects is characterised by cohesion which is defined as the collaborative spirit between actors (Dietrich et al., 2010; Hoegl and Gemuenden, 2001) and the resultant of all forces acting upon members to remain in the group (Festinger in Lin and Peng, 2010). Cohen and Bailey (1997) found that cohesion is one of the key issues that determine the individual's willingness to engage in collaboration. However, as cohesion is not frequently mentioned as a collaboration factor it was excluded from the study. At an individual and team level, collaborative work predicts task and team performance (Chiocchio et al., 2011a). Following a comprehensive literature review, it was decided to only focus on the following factors that influence the degree of collaboration in a project team, namely, relationships, coordination, proximity, commitment, conflict and incentives. These factors are discussed in more detail below.

2.2.1 Relationships factor. A relationship is a way in which two or more people or things are connected, or the state of being connected (Oxford University Press, 2017). Relationships are important in projects mainly because they form the basis for collaboration in the team which ultimately influences project performance. Research on the relations between project actors and their effect on project performance is widely researched (Ahola, 2009; Artto et al., 2008; Dietrich et al., 2010). Most of the literature, however, focusses only on collaboration in customer-supplier relationships specifically in the construction industry (Bresnen, 2007; Dietrich et al., 2010; Errasti et al., 2007). Collaboration processes improve the relationships between individuals or organisations. However, the nature of these relationships may vary depending on their strength (Granovetter in Dietrich et al., 2010). Successful collaboration induces hope and expectation within the team members for future collaborations which provide motivation in partnering relationships (Bresnen and Marshall, 2000; Dietrich et al., 2010). There are several challenges involved in establishing organisational project relationships:

- discontinuity of demand, i.e., infrequent projects lead to difficulty increasing the level of trust and commitment in the project team (Eloranta, 2007);

- dependent on the success of a single project (Hadjikhani in Dietrich et al., 2010);

- uniqueness of project transactions; and

- the complexity of actor network (Dietrich et al., 2010; Skaatesa and Tikkanen, 2003).

To encourage the development of relationships or social capital in projects, it is important to promote collaborative practises which involve the exchange of knowledge between team members (Dietrich et al., 2010). Uzzi in Dietrich et al. (2010) describe relationships in which organisations operate in a truly collaborative mode to achieve a common goal or gain mutual benefits, as embedded relations which are generally characterised by trust and commitment.

2.2.2 Coordination factor. High-quality coordination is defined by Hoegl and Gemuenden (2001) as the shared understanding of mutual goals, related activities, interdependencies between the activities and the status of member contributions. Coordination is one of the factors that determine the quality of collaboration (Bedwell et al., 2012; Chiocchio et al., 2011a; Dietrich et al., 2010; Hoegl and Gemuenden, 2001; LePine et al., 2008). High coordination is a prerequisite for fluent interactions in collaborative settings and ensures harmonised and synchronized co-action (Dietrich et al., 2010). Coordination in projects is mainly used to align the team with the project goal. Congruent or collaborative goals weaken conflicts and increase the quality of collaboration (O'Leary-Kelly et al., 1994; Pinto et al., 1993) as well as increasing the exchange of knowledge between members (Tjosvold in Dietrich et al., 2010). Coordination is often perceived to be a way in which the project team and the project outcomes can be controlled to meet expectations. 
Martín-Rodríguez et al. (2005) add that communication and coordination mechanisms, policies, protocols and standardised documentation may benefit collaborative processes. For example, Pinto et al. (1993) examined inter-unit collaboration in projects and found that team rules improve the collaboration. Similarly, the results of Silén-Lipponen et al. (2002) show that rules and procedures represent an important role in coordination and collaboration between professionals. Norms regarding the rules and procedures that must be followed in a project increase the predictability of collaborative actor behaviour. High-quality collaboration requires each participant to accept and respect required effort norms (Dietrich et al., 2010). When the team collaborates by coordinating their efforts, the cost of controlling and the probability of failure is reduced (Ahola, 2009; Dubois and Gadde, 2000; Ingram and Baum, 2001).

2.2.3 Proximity factor. Project team-based collaboration often spans across national borders and/or between organisations. Studies have shown the positive effects of physical proximity on collaborative behaviour (Dietrich et al., 2010). Physical proximity is defined as nearness in space and in the context of projects, proximity refers to the physical distance between project team members. Van den Bulte and Moenaert (1998) examined R\&D team co-location and found a positive relationship between co-location and the frequency of communication. Other empirical studies have shown that co-locating people enables informal communication, enhances the creation of shared understanding and increases cohesion between collaborative actors (Kahn and McDonough, 1997; Moodysson and Jonsson, 2007; Pinto et al., 1993). A study by Arslanian-Engoren in Dietrich et al. (2010) confirms this by stating that physical proximity has a positive effect on collaboration.

2.2.4 Commitment factor. Commitment is characterised by the acceptance of and strong belief in the goals and values of the project, the willingness to engage in the project and the desire to maintain membership in the project (Hoegl et al., 2004). In projects, commitment is one of the key success factors for interpersonal and interorganisational collaboration (Buvik and Rolfsen, 2015; Dietrich et al., 2010; Herscovitch and Meyer, 2002; Mohr and Spekman, 1994). According to Bresnen and Marshall (2000), an actor's commitment to project tasks increases the collaboration quality. Hoegl et al. in Chen et al. (2010) found that commitment also has a positive effect on teamwork quality in product development projects. Empirical studies prove similar results in cross-disciplinary collaboration in a hospital context (Liedtka and Whitten in Dietrich et al., 2010). Furthermore, Vandenberghe et al. (2004) found that commitment has a direct and indirect effect on job performance through commitment to the supervisor and organisational commitment, respectively. Commitment increases a collaborator's genuine interest to participate, engage in mutual support, and sets actors' priorities to favour the collaborative task at hand (Dietrich et al., 2010).

2.2.5 Conflict factor. Some researchers argue that conflicts are "characteristic" of collaborative projects and should be managed by formal and informal governance mechanisms or coordination to strengthen the relationship between the collaborating actors (Vaaland, 2004). It is important to address conflict in a project as the increased complexity and diversity of the technical workforce in teams will increase workplace tensions (Dietrich et al., 2010; Farris and Cordero, 2002). The relationship between conflict resolution and collaboration has been tested in empirical studies. For example, Tjosvold et al. (2003) showed that a positive attitude to conflict is positively related to collaborative interaction in teams. Some studies have found a negative relationship between conflict and collaboration (Duarte and Davies in Dietrich et al., 2010), while others also emphasise the positive aspects of conflicts (Vaaland and Håkansson, 2003) as task conflict has a beneficial effect on the performance of decision-making teams (O'Neill et al., 2013). De Dreu and Weingart (2003) executed meta-analysis on the effects of relational and task conflicts on team performance and team member satisfaction and found that both of these conflict types are negatively
Trust and collaboration in project teams 
IJMPB

11,2

related to team performance and team member satisfaction. These findings strengthen the notion that resolving conflicts has a direct positive effect on collaboration quality (Dietrich et al., 2010; O'Leary-Kelly et al., 1994; Pinto et al., 1993).

2.2.6 Incentives factor. Incentives are things that motivate or encourage someone to do something and are often used in projects to boost project team performance and collaboration (Oxford University Press, 2017). According to Dietrich et al. (2010), the alignment of incentives is one of at least eight interrelated issues that impact directly on the fluency of collaboration between different project actors. To guarantee that each of the collaborating actors support the achievement of the common goal and to ensure that mutual support exists between them, the incentives of the different actors should be aligned. When Faerman et al. (2001) studied public-private collaboration, they found that the alignment of incentives served as one of the most important issues that related to success of the collaborative process. Similarly, Dietrich et al. (2010) state that alignment of incentives are an important factor for effective collaboration. A study by Bresnen and Marshall (2000) reveals, however, that most of the incentive systems used in projects do not provide expected motivation for collaborating actors. They advise, therefore, that individual differences, social relations and a balance between extrinsic and intrinsic rewards and incentives must be considered to improve the degree of collaboration in the project.

\subsection{PM success construct}

Success can mean different things to different people (Freeman and Beale in Jugdev and Müller, 2005). The requirements of each project stakeholder will differ and, therefore, their perception of what constitutes success will vary. The stakeholder's satisfaction with the project is determined as the difference between his perception of the project's success vs his expectations thereof (Koelmans, 2004; Maylor, 2003). A stakeholder's perception of project success can be influenced by issues such as the responsiveness of the team to stakeholder requests, project communication, degree of collaboration and/or trust in the team, etc.

Before the constituents of project success are discussed in more detail, it is important to distinguish between project success (measured against the overall objectives of the project) and PM success (measured against the widespread and traditional measures of performance against cost, time and quality) (Cooke-davies, 2002; De Wit, 1988; Jugdev and Müller, 2005). The second distinction one must make is the difference between success criteria (the measures by which success or failure of a project or business will be judged) and success factors (those inputs to the management system that lead directly or indirectly to the success of the project or business) (Cooke-davies, 2002). The success of a project is not only dependent on how the project performs in terms of its success criteria but it is also dependent on the stakeholders' perception of project success.

PM success is measured by "things-related" criteria such as the budget, schedule and quality of the project deliverable (hereafter collectively referred to as project performance) and "people-related" criteria such as communication, trust and collaboration which determine the team morale and stakeholder satisfaction in the project, amongst others (Koelmans, 2004). Furthermore, literature states that there is an additional construct, knowledge integration and innovation that influences PM success by bridging the gap between the "things-related" and "people-related" factors. Both project performance and knowledge integration and innovation are discussed in more detail below. Several factors that are beyond the scope of this paper can also influence PM success. These include for example the level of risk accepted, the match between organisational capabilities and project requirements and several aspects of the planning process.

2.3.1 Project performance factor. Project performance is concerned with the attainment and continuous measurement of the project determinants, time, cost and quality to establish 
the project's relative success. These three project measures are concerned with the internal efficiency of PM tasks (Dalcher and Societies, 2009). Project performance is an important determinant of PM success, as the effectiveness of projects needs to be considered on a regular basis throughout the course of the project to establish the project's relative success (Dalcher and Societies, 2009; Mir and Pinnington, 2014).

2.3.2 Knowledge integration and innovation factor. Knowledge integration is a project team or organisation's effective use of the ideas and information available to it (Cambridge University Press, 2017). Innovation involves deliberate application of information, imagination and initiative to derive greater or different values from resources, and includes all processes by which new ideas are generated and converted into useful products (Web Finance Inc., 2017). Knowledge integration and innovation is a product of knowledge exchange/transfer and collaboration which is supported by an environment of trust. Research indicates that an appropriate level of collaboration between customer and supplier reduces the costs of controlling, decreases the probability of failure and creates potential for innovations and learning (Ahola, 2009; Dubois and Gadde, 2000; Ingram and Baum, 2001). Henderson and Cockburn in Dietrich et al. (2010) found that higher project performance was associated with knowledge transfer mechanisms that actively encouraged the exchange of information across organisational units and across organisational boundaries. To achieve PM success, open channels for knowledge exchange need to be available, which allows new external knowledge to be imported and synthesised with existing internal knowledge so that the knowledge can be integrated into the project (Henderson and Cockburn in Dietrich et al., 2010). Knowledge integration and innovation was shown to exert significant positive effects on project performance and proper knowledge acquisition and dissemination was found to be crucial for learning by increasing the variability of project performance (Yang, 2005). Thus, the acquisition and integration of specialized knowledge, especially tacit, influences the outcome of project success (Leonard-Barton in Brady, 2004; Teece et al. in Smyth et al., 2010).

The theoretical link between the constructs trust, collaboration and PM and their factors as discussed above and summarised in Table I are presented as a structural model in Figure 1. The arrow represents the direction of hypothesised influences in the structural model. The corresponding hypotheses are as follows:

H1. PM success becomes more likely as the degree of collaboration increases.

H2. The degree of collaboration increases as the level of trust in the project increases.

\section{Research methodology}

A questionnaire was designed for respondents to assess the level of trust, the degree of collaboration and the perceived likelihood of PM success they had experienced in the project teams they had participated in. Respondents were asked to rate their response, on a ten-point scale, regarding the relevant factors impacting the constructs and overall success of a project. A sample of the questionnaire is shown in Table AI.

Before undertaking the industry-wide survey, a pilot study was conducted among a six-member project reference group explaining the research intent and the questions in order to validate the contents for accurate translation of the overall model. Based on the feedback received, modifications were made to the content and the organisation of the questionnaire to improve accuracy and number of responses.

Purposive sampling was used. The questionnaire was distributed to the members of five different open and closed PM LinkedIn groups. The questionnaire was also sent to 19 PM experts who were identified from literature and it was circulated to current students
Trust and collaboration in project teams 
IJMPB

11,2

442

\begin{tabular}{|c|c|c|c|c|c|}
\hline \multicolumn{2}{|c|}{ Level of trust construct } & \multicolumn{2}{|c|}{ Degree of collaboration construct } & \multicolumn{2}{|c|}{$\begin{array}{c}\text { Project management success } \\
\text { construct }\end{array}$} \\
\hline Variable & Support & Variable & Support & Variable & Support \\
\hline $\begin{array}{l}\text { Knowledge } \\
\text { exchange }\end{array}$ & $\begin{array}{l}\text { Daim et al. } \\
\text { (2012), Lesko } \\
\text { and } \\
\text { Hollingsworth } \\
\text { (2010), } \\
\text { Levesque } \\
\text { (2005) }\end{array}$ & Relationships & $\begin{array}{l}\text { Ahola (2009), Artto et al. } \\
\text { (2008), Bresnen and Marshall } \\
\text { (2000), Dietrich et al. }(2010)\end{array}$ & $\begin{array}{l}\text { Project } \\
\text { performance }\end{array}$ & $\begin{array}{l}\text { Dalcher and } \\
\text { Societies (2009), } \\
\text { Mir and } \\
\text { Pinnington } \\
\text { (2014) }\end{array}$ \\
\hline $\begin{array}{l}\text { Imported } \\
\text { trust }\end{array}$ & $\begin{array}{l}\text { Daim et al. } \\
(2012)\end{array}$ & Coordination & $\begin{array}{l}\text { Ahola (2009), Bedwell et al. } \\
\text { (2012), Chiocchio et al. (2011a), } \\
\text { Dietrich et al. (2010), Hoegl } \\
\text { et al. (2004), Ingram and Baum } \\
\text { (2001), LePine } \text { et al. (2008), } \\
\text { Martín-Rodríguez et al. (2005) }\end{array}$ & $\begin{array}{l}\text { Knowledge } \\
\text { integration } \\
\text { and } \\
\text { innovation }\end{array}$ & $\begin{array}{l}\text { Ahola (2009), } \\
\text { Brady (2004), } \\
\text { Dietrich } \text { et al. } \\
\text { (2010), Dubois } \\
\text { and Gadde } \\
\text { (2000), Ingram } \\
\text { and Baum } \\
\text { (2001), Smyth } \\
\text { et al. (2010), } \\
\text { Yang (2005) }\end{array}$ \\
\hline Expectations & $\begin{array}{l}\text { Chiocchio et al. } \\
\text { (2011a), Daim } \\
\text { et al. (2012), } \\
\text { Lesko and } \\
\text { Hollingsworth } \\
\text { (2010), Tyler } \\
\text { (2003) }\end{array}$ & Proximity & $\begin{array}{l}\text { Dietrich et al. (2010), Kahn and } \\
\text { McDonough (1997), } \\
\text { Moodysson and Jonsson } \\
\text { (2007), Pinto et al. (1993), Van } \\
\text { den Bulte and Moenaert } \\
\text { (1998) }\end{array}$ & & \\
\hline Risk & $\begin{array}{l}\text { Daim et al. } \\
(2012)\end{array}$ & Incentives & $\begin{array}{l}\text { Bresnen and Marshall (2000), } \\
\text { Buvik and Rolfsen (2015), } \\
\text { Chen et al. (2010), Dietrich } \\
\text { et al. (2010), Herscovitch and } \\
\text { Meyer (2002), Mohr and } \\
\text { Spekman (1994) } \\
\text { De Dreu and Weingart (2003), } \\
\text { Dietrich et al. (2010), O'Neill } \\
\text { et al. (2013), Tjosvold et al. } \\
\text { (2003), Vaaland and } \\
\text { Håkansson (2003) } \\
\text { Bresnen and Marshall (2000), } \\
\text { Dietrich et al. (2010), Faerman } \\
\text { et al. (2001) }\end{array}$ & & \\
\hline
\end{tabular}

Table I.

Summary of construct variables and alumni of PM courses. This target population was chosen to ensure that respondents had detailed knowledge of projects and occupied key positions of responsibility within a project environment, i.e., project leaders (i.e. project/programme managers), project team members, project stakeholders (e.g. subcontractor, functional manager, regulatory authority, external party, etc.) and project sponsors/clients. The survey was conducted by means of an online, self-administered questionnaire using Qualtrics. Data were collected from a total of 270 international self-selected respondents working on medium size projects in various industries, for both government and private institutions. Of the 270 responses received only 151 (56 per cent) were valid and complete. Table II shows the profile of the respondents for each of the typical roles in the project in terms of gender, age, field of work and nature of business entity. The valid data set was analysed using IBM SPSS Statistics 22 and its structural equation component AMOS. 


\begin{tabular}{|c|c|c|c|c|c|c|c|}
\hline & $\begin{array}{l}\text { Project } \\
\text { leader }\end{array}$ & $\begin{array}{l}\text { Project team } \\
\text { member }\end{array}$ & $\begin{array}{c}\text { Project } \\
\text { sponsor/ } \\
\text { client }\end{array}$ & $\begin{array}{l}\text { Other project } \\
\text { stakeholders }\end{array}$ & Other & $\begin{array}{l}\text { Total } \\
\text { respondents }\end{array}$ & $\begin{array}{l}\text { collaboration } \\
\text { in project }\end{array}$ \\
\hline \multicolumn{7}{|l|}{ Gender of respondents } & teams \\
\hline Male & 53 & 47 & & 8 & 7 & 115 & \\
\hline Female & 16 & 14 & & 1 & 5 & 36 & 412 \\
\hline Total & 69 & 61 & 0 & 9 & 12 & 151 & 443 \\
\hline \multicolumn{8}{|l|}{ Respondent age } \\
\hline $20-29$ & 8 & 18 & & 4 & 1 & 31 & \\
\hline $30-39$ & 32 & 30 & & 3 & 8 & 73 & \\
\hline $40-49$ & 15 & 8 & & 1 & 2 & 26 & \\
\hline $50-59$ & 11 & 5 & & 1 & 0 & 17 & \\
\hline $60+$ & 4 & 0 & & 0 & 0 & 4 & \\
\hline Total & 70 & 61 & 0 & 9 & 11 & 151 & \\
\hline \multicolumn{8}{|l|}{ Principal industry } \\
\hline Agriculture & 1 & & & & & 1 & \\
\hline Construction & 9 & 10 & & & 1 & 20 & \\
\hline Finance, insurance, real estate & 2 & 1 & & 1 & & 4 & \\
\hline Government & 16 & 8 & & & 2 & 26 & \\
\hline Health care & 2 & & & & & 2 & \\
\hline Information technology & 6 & 7 & & 1 & 1 & 15 & \\
\hline Manufacturing & 5 & 4 & & 1 & 2 & 12 & \\
\hline Mining & 5 & 10 & & 1 & & 16 & \\
\hline Services & 7 & 5 & & & 1 & 13 & \\
\hline Transportation & 3 & 5 & & 3 & & 11 & \\
\hline Communication, utilities & 5 & 2 & & 1 & 2 & 10 & \\
\hline Non-profit & 2 & & & & & 2 & \\
\hline Other & 6 & 9 & & 1 & 3 & 19 & \\
\hline Total & 69 & 61 & 0 & 9 & 12 & 151 & \\
\hline \multicolumn{8}{|l|}{ Business entity } \\
\hline Sole proprietor & 1 & 2 & & & & 3 & \\
\hline Closed corporation & & & & & & 0 & \\
\hline Private company & 26 & 28 & & 5 & 4 & 63 & \\
\hline Public company & 7 & 6 & & 1 & 3 & 17 & \\
\hline State owned company & 14 & 13 & & 2 & 4 & 33 & \\
\hline Personal liability company & 2 & & & & & 2 & \\
\hline A not for profit business & 1 & 1 & & & & 2 & \\
\hline Government & 17 & 9 & & 1 & 1 & 28 & \\
\hline Other business entity & 1 & 2 & & & & 3 & \\
\hline Total & 69 & 61 & 0 & 9 & 12 & 151 & \\
\hline \multicolumn{8}{|c|}{ Number of stakeholders communicated with in typical project $t^{a}$} \\
\hline $1-5$ & 7 & 7 & & 2 & 1 & 17 & \\
\hline $6-20$ & 32 & 18 & & 3 & 3 & 56 & \\
\hline $21-50$ & 12 & 7 & & & 3 & 22 & \\
\hline $51-100$ & 1 & 3 & & & & 4 & \\
\hline $101-500$ & 1 & & & & & 1 & \\
\hline \multirow{2}{*}{\multicolumn{4}{|c|}{$\begin{array}{l}\text { Respondents that chose not to } \\
\text { answer this question }\end{array}$}} & & & 1 & Table II. \\
\hline & & & & & & 50 & $\begin{array}{l}\text { Summary of } \\
\text { Sumpos }\end{array}$ \\
\hline Total & 54 & 35 & 0 & 5 & 7 & 151 & typical project role \\
\hline
\end{tabular}


IJMPB

11,2

444

\section{Model specification and refinements}

Analysing the initial SEM posited in Figure 1, based on theoretical expectations and past empirical findings, would have been premature. A SEM model consists of two parts - a measurement component and a structural component. A feasible model should be selected based on the recommended goodness-of-fit (GOF) measures of the measurement parts of the model. Only a model that satisfies both theoretical expectations and GOF should be selected for the final SEM analysis that includes the structural regression paths (Doloi et al., 2011; Molenaar et al., 2000). Thus, CFA was first performed for each of the constructs separately to determine their relevance to the model before analysing the complete model.

\subsection{Modelling the constructs}

Typically, CFA and SEM utilise the method of maximum likelihood (ML) to obtain the parameter estimates for the regression weights, the assumptions being that the data are measured on a continuous scale and have a multivariate normal distribution (Byrne, 2010). CFA and SEM estimate a variance-covariance matrix that resembles the sample variance-covariance matrix as closely as possible; however, both variances and co-variances are sensitive to kurtosis. As data become increasing non-normal, the $\chi^{2}$ value for ML estimation becomes excessively large. This situation encourages researchers to seek further modification of their hypothesised model in an effort to obtain an adequate fit for the data. However, these efforts can lead to inappropriate and nonreplicable modifications to otherwise theoretically adequate models. Second, when sample sizes are small (even in the event of multivariate normality), the ML estimators yield $\chi^{2}$ values that are somewhat inflated and a greater proportion of the model fails to converge or results in an improper solution. Third, when data are non-normal, fit indexes such as the Tucker-Lewis (1973) index and the comparative fit index (Bentler, 1990) yield values that are modestly underestimated. Finally, non-normality can lead to low standard errors with moderate to severe underestimation, which causes regression paths and factor/error co-variances to be statistically significant although they may not be so in the population (Byrne, 2010).

Tests of normality were hence performed to assess whether the criterion for multivariate kurtosis was met. Byrne (2010) states that rescaled kurtosis values greater than or equal to 7 for the variables indicate an early departure from normality. Mardia's normalised estimate greater than 5 is indicative of non-normally distributed data. For the construct level of trust, Mardia's coefficient is 24.5 and for degree of collaboration, it is 63.6. Since the data were measured on a Likert scale and the important assumption of multivariate kurtosis is evidently violated, the method of unweighted least squares (ULS) was used to obtain the parameter estimates. Kaplan in Arbuckle (2008) explains that the ULS method is actually a type of ordinary least squares estimation that minimises the sum of squared differences between sample and model-implied co-variances.

All the factors for the level of trust model had positive regression weight estimates except for the factor risk (item 20) that had an estimate of -0.031 . This item also had a very small squared multiple correlation of 0.01 , i.e., it is estimated that the error variance of risk is approximately 99 per cent of the variance of itself. Therefore, risk as a factor or indicator of the level of trust was not relevant. This is an interesting finding as it contradicts Daim et al. (2012) who state that risk can facilitate the development of high initial and final trust in a team if the members successfully cope with technical uncertainties and take initiative in the project. Risk was consequently removed from the second order CFA for the level of trust, which resulted in all regression weight estimates being positive. The fit indices, displayed in Table III, all met the generally accepted criteria (values $>0.95$ where 0 indicates no fit and 1 perfect fit).

Before the degree of collaboration was modelled, item 25_1 in Figure 1 (a factor for relationships) was removed as there were too much missing data. The model for degree of collaboration also had positive regression weight estimates and adequate fit indices (Table III). 


\subsection{Estimating the model}

Once it was established that a suitable fit was obtained for the level of trust and degree of collaboration, the next step was to estimate the entire model. The standardised regression weight estimates which indicate the relative strength of each specific parameter estimate in the model are given in Table IV. It is important to emphasise the strength of the links between the level of trust and the degree of collaboration (value of 0.768) and degree of collaboration and PM success (value of 0.792). The squared multiple correlations estimates in Table $\mathrm{V}$ indicate the strength of association between the parameter and its construct and the fit indices are shown in Table VI.

By eliminating one of the factors, risk, from the degree of collaboration construct, the $\mathrm{GOF}$ indices attained the recommended levels. This model was adopted to fit level of trust,

\begin{tabular}{lcc}
\hline Goodness-of-fit (GOF) measure & Level of trust & Degree of collaboration \\
\hline GFI & 0.997 & 0.972 \\
AGFI & 0.990 & 0.960 \\
NFI & 0.992 & 0.945 \\
RFI & 0.984 & 0.931 \\
\hline
\end{tabular}

Trust and collaboration in project teams

\begin{tabular}{|c|c|}
\hline & Estimate \\
\hline Collaboration $\leftarrow$ trust & 0.768 \\
\hline Success $\leftarrow$ collaboration & 0.792 \\
\hline Expectations $\leftarrow$ trust & 0.869 \\
\hline Imported trust $\leftarrow$ trust & 0.497 \\
\hline Knowledge exchange $\leftarrow$ trust & 0.814 \\
\hline Conflict $\leftarrow$ collaboration & 0.454 \\
\hline Commitment $\leftarrow$ collaboration & 0.810 \\
\hline Proximity $\leftarrow$ collaboration & 0.432 \\
\hline Coordination $\leftarrow$ collaboration & 0.899 \\
\hline Relationships $\leftarrow$ collaboration & 0.842 \\
\hline Incentives $\leftarrow$ collaboration & 0.392 \\
\hline Knowledge integration and innovation $\left(\mathrm{q} 26 \_1\right) \leftarrow$ success & 0.902 \\
\hline Project performance $\left(\mathrm{q} 26 \_2\right) \leftarrow$ success & 0.751 \\
\hline
\end{tabular}

Table III. GOF measures for trust and collaboration ULS

\begin{tabular}{lc}
\hline Parameter & Estimate \\
\hline Expectations & 0.756 \\
Imported trust & 0.247 \\
Knowledge exchange & 0.663 \\
Collaboration & 0.591 \\
Conflict & 0.206 \\
Commitment & 0.656 \\
Proximity & 0.187 \\
Coordination & 0.809 \\
Relationships & 0.710 \\
Incentives & 0.154 \\
Success & 0.628 \\
Knowledge integration and innovation (Q26_1) & 0.813 \\
Project performance (Q26_2) & 0.564 \\
\end{tabular}

Table IV.

Standardised regression weights of final SEM model

Project performance (q26_2) $\leftarrow$ succes 
IJMPB

11,2

446

degree of collaboration and overall PM success, and is adequately supported based on the essential GOF measures. The GFI index value of 0.96 and the AGFI index value of 0.949 both indicate an acceptable model fit to the data. The standardised root mean residual value is 0.077 which is below the recommended upper limit of 0.08 . Furthermore, all the other indices that are routinely reported, namely, normal fit index and relative fit index, have values above 0.9 , providing strong evidence that the fit between the measurement model and the data is acceptable (Doloi et al., 2011).

The method of ULS does not provide standard errors, hence critical ratios with the corresponding $p$-values cannot be calculated to assess if parameter estimates differ significantly from zero. In order to evaluate the stability of the parameter estimates, 90 per cent bootstrap confidence intervals were calculated for the model and are provided in Table VII.

Goodness-of-fit (GOF) measure

Goodness-of-fit index (GFI)

Adjusted goodness-of-fit index (AGFI)

0.949

Normal fit index (NFI)

0.936

Relative fit index (RFI)

0.926

Table VI.

Standardised root mean residual (SRMR)

0.077

\begin{tabular}{|c|c|c|c|}
\hline Parameter & Estimate & Lower & Upper \\
\hline Collaboration $\leftarrow$ trust & 0.823 & 0.578 & 1.344 \\
\hline Success $\leftarrow$ collaboration & 1.201 & 0.857 & 1.855 \\
\hline Q21 (imported trust) $\leftarrow$ trust & 1.000 & 1.000 & 1.000 \\
\hline Expectations $\leftarrow$ trust & 1.459 & 0.925 & 3.219 \\
\hline Q18_1 $\leftarrow$ expectations & 0.691 & 0.414 & 0.883 \\
\hline Q18_2 $\leftarrow$ expectations & 0.756 & 0.536 & 0.957 \\
\hline Q18_3 $\leftarrow$ expectations & 1.000 & 1.000 & 1.000 \\
\hline Knowledge exchange $\leftarrow$ trust & 1.229 & 0.775 & 2.754 \\
\hline Q19_1 $\leftarrow$ knowledge exchange & 1.007 & 0.661 & 1.263 \\
\hline Q19_2 $\leftarrow$ knowledge exchange & 1.000 & 1.000 & 1.000 \\
\hline Conflict $\leftarrow$ collaboration & 0.209 & 0.069 & 0.296 \\
\hline Q23_1 $\leftarrow$ conflict & 1.073 & 0.305 & 2.702 \\
\hline Q23_2 $\leftarrow$ conflict & 1.000 & 1.000 & 1.000 \\
\hline Commitment $\leftarrow$ collaboration & 1.000 & 1.000 & 1.000 \\
\hline Q22_1 $\leftarrow$ commitment & 0.623 & 0.395 & 0.818 \\
\hline Q22_2 $\leftarrow$ commitment & 1.000 & 1.000 & 1.000 \\
\hline Q24_5 (proximity) $\leftarrow$ collaboration & 0.978 & 0.558 & 1.421 \\
\hline Coordination $\leftarrow$ collaboration & 1.264 & 1.016 & 1.667 \\
\hline Q24_1 $\leftarrow$ coordination & 0.757 & 0.601 & 0.926 \\
\hline Q24_2 $\leftarrow$ coordination & 0.655 & 0.423 & 0.951 \\
\hline Q24_3 $\leftarrow$ coordination & 0.829 & 0.696 & 0.969 \\
\hline Q24_4 $\leftarrow$ coordination & 1.000 & 1.000 & 1.000 \\
\hline Relationships $\leftarrow$ collaboration & 1.058 & 0.626 & 1.634 \\
\hline Q25_2 $\leftarrow$ relationships & 0.920 & 0.647 & 1.689 \\
\hline Q25_3 $\leftarrow$ relationships & 0.963 & 0.733 & 1.485 \\
\hline Q25_4 $\leftarrow$ relationships & 1.000 & 1.000 & 1.000 \\
\hline Incentives $\leftarrow$ collaboration & 0.935 & 0.552 & 1.472 \\
\hline Q24_6 $\leftarrow$ incentives & 0.675 & 0.371 & 0.915 \\
\hline Q24_7 $\leftarrow$ incentives & 1.000 & 1.000 & 1.000 \\
\hline Q26_1 (knowledge integration and innovation) $\leftarrow$ success & 1.000 & 1.000 & 1.000 \\
\hline Q26_2 (project performance) $\leftarrow$ success & 0.788 & 0.547 & 0.944 \\
\hline
\end{tabular}

Table VII.

Bootstrap confidence intervals for final SEM model
Q26_1 (knowledge integration and innovation) $\leftarrow$ success
Q26_2 (project performance) $\leftarrow$ success


The procedure of "bootstrapping" is a way to handle multivariate non-normal data (West et al., 1995; Yung and Bentler, 1996; Zhu, 1997). Bootstrapping serves as a resampling procedure by which the original sample is considered to represent the population. Multiple subsamples of the same size as the parent sample are then drawn randomly, with replacement, from this population and provide the data for empirical investigation of the variability of the parameter. From Table VII, it is clear that all coefficients differ significantly from zero, as zero is not included in any of the confidence intervals.

\section{Results of SEM analysis and discussion}

Figure 2 depicts the final model after deleting the redundant path (risk as a factor for the level of trust). As hypothesised, all the path coefficients are positive, confirming the relevance of the measured factors in the model. The final SEM results suggest that the level of trust correlates strongly with the degree of collaboration (regression coefficient of 0.823 and standardised regression coefficient of 0.768). The model as a whole accounts for why the endogenous variables, trust and collaboration, co-vary with each other and also with the exogenous variables (Kline, 2010). Furthermore, the degree of collaboration strongly influences PM success with a standardised regression coefficient $=0.792$.

Expectations was found to have the highest association with the level of trust in a project (standardised regression coefficient $=0.869$ ) and imported trust (with a standardised regression coefficient of 0.497 ) had the least influence. These findings are aligned with literature as the expectation factor is embedded in the very definition of trust as formulated by Kadefors (2004) and Rousseau et al. (1998), which is that trust is a psychological state

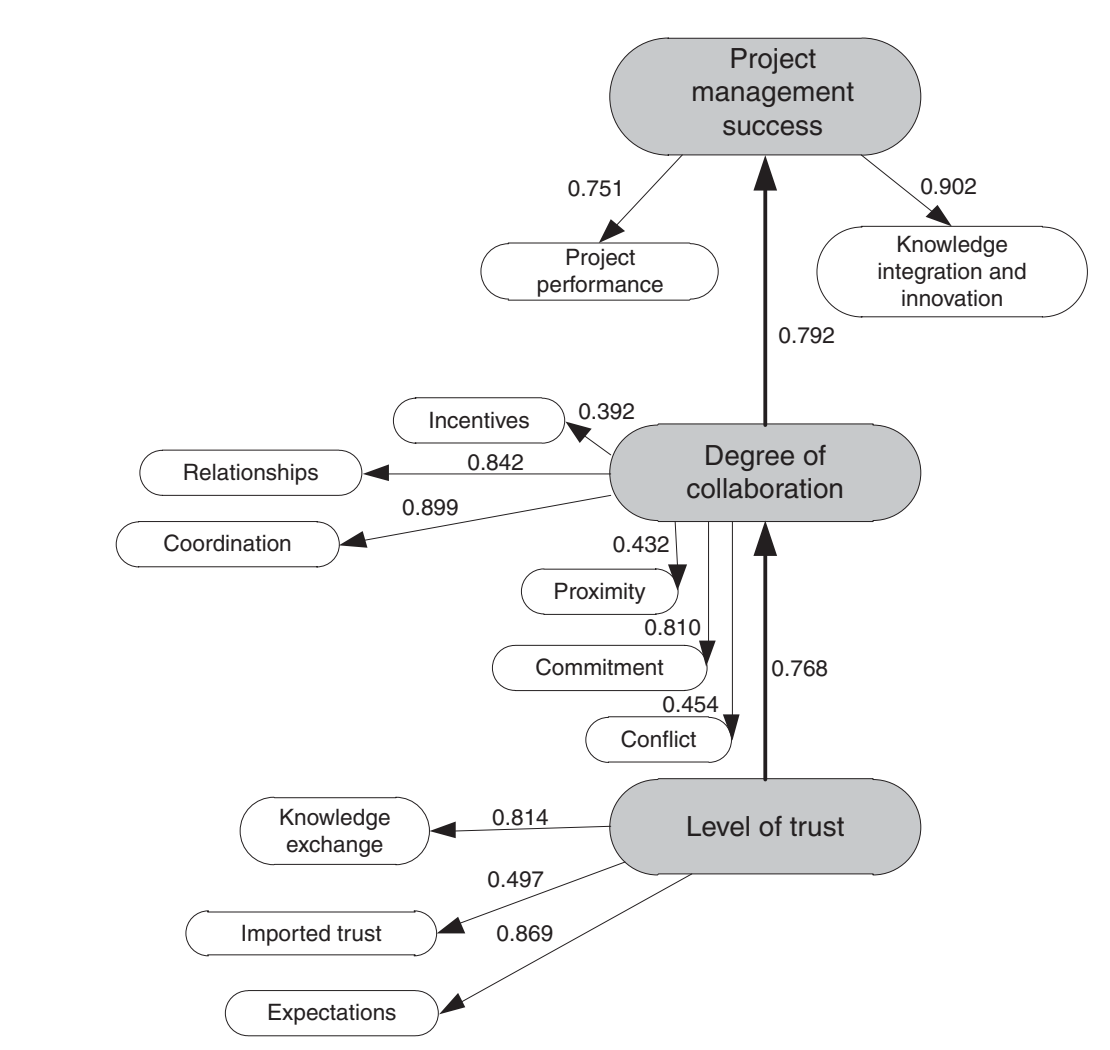

\begin{abstract}
by Kadefors (2004) and Rousseau et al. (1998), which is that trust is a psychological state
\end{abstract}
Trust and collaboration in project teams

Figure 2.

Final model with standardised path coefficients 
IJMPB

11,2

448

comprising the intention to accept vulnerability based upon positive expectations of the intentions or behaviour of another. Similarly, imported trust has in several other instances been found to improve the level of trust in a project team (Grabher, 2002; Meyerson et al., 1996; Mumbi and McGill, 2008).

The fact that risk was removed since it was inconsequential in determining the level of trust in a project alters the widely accepted view that the relationship between risk and trust is reciprocal; an acceptable degree of risk is responsible for an increase in the level of trust in a project (Bond-Barnard et al., 2014; Daim et al., 2012).

Coordination and relationships had the highest and second highest correlation (with a standardised regression coefficient $=0.899$ and 0.842 , respectively) with the degree of collaboration. This finding supports literature which emphasises the importance of team member relationships to enable collaboration (Manu et al., 2015). Due to the high uncertainties in project environments, firms are better able to respond to new information and approach work in a flexible manner when relationships are driven by trust, thus contributing to significant time and cost savings (Swan et al., 2002). Project actors are also less likely to withhold information deliberately and act against the interest of the overall project when relationships are trust driven, hence resulting in open and reliable flow of information (McDermott et al., 2004).

Among the six factors determined by the degree of collaboration, coordination (standardised regression coefficient of 0.899 ) had the most influence and incentives (standardised regression coefficient of 0.392) the least. It is interesting that team member incentives had the least influence on the degree of collaboration of all the factors as project manager incentives are one of the strongest predictors of project construction schedule, in a study conducted by Scott-Young and Samson (2008). However, they concede that further research is warranted on the potential impact of incentives for project team members. This study goes some way in investigating this topic.

One of the unexpected findings from the study was the high measure of association between two factors of collaboration, namely, proximity and incentives. Co-location has long been considered an essential component for superior project performance and goal achievement. However, in Scott-Young and Samson's (2008) empirical study, there was no significant relationship between team co-location and project success or any of the other factors they identified such as manager incentives. The reason for this significant association could be that physical proximity to colleagues serves as an incentive for project team members. Physical proximity promotes collaboration (Arslanian-Engoren in Dietrich et al., 2010), therefore, when the project team is able to work is close proximity to each other they collaborate more which also incentivises them.

The results in Tables IV and VII support the links between level of trust, degree of collaboration and success in a project, which validates both $H 1$ - PM success becomes more likely as the degree of collaboration increases - and $H 2$, the degree of collaboration increases as the level of trust in the project increases. The findings are limited to practitioners' perceptions who are part of the study's target population.

\subsection{The relationship between level of trust and degree of collaboration}

This study has confirmed the hypothesis that the level of trust predicts the degree of collaboration, which in turn, predicts the success of the project. When practitioners promote trust and collaboration in a project, it is more likely that the project will be a success in terms of time, cost and quality objectives but more specifically that it will be perceived to be a success by all the stakeholders involved. It has been revealed that the expectations that project stakeholders have of each other as well as the exchange of knowledge between them is integral in determining the level of trust in a project. Moreover, coordination and the relationship between stakeholders are crucial for collaboration, which together with trust leads to PM success. 
The strong relationship between trust and collaboration validates previous research which found that trust and respect is the second most important indicator for team integration practice (Ibrahim et al., 2015). Furthermore, the requirement to trust other team members and recognise that they are trying to achieve the very best results of which they are capable (i.e. expectations) is one of the most fundamental differences in the collaborative approach according to the Strategic Forum for Construction (2003) in Ibrahim et al. (2015).

\section{Conclusions}

The results corroborate the $H 1$ that PM success becomes more likely as the degree of collaboration increases and the $H 2$ that the degree of collaboration increases as the level of trust in the project increases. The model, in spite of a relatively small sample size, produced good results which are commensurate with similar studies (Doloi et al., 2011). Empirical evidence is provided that indicates that PM success becomes more likely as the degree of collaboration improves, which in turn, is influenced by an increase in the level of trust between team members. These findings address the gap in literature as to the factors that determine trust, collaboration and PM success and the strength of the association/link between them. Some practical insights for PM are that by promoting collaboration and trust in a project by taking cognisance of each construct's factors, the likelihood of PM success could improve. The results of the study may also provide insight into teaching and learning in tertiary education in terms of professionalism and integrity issues.

It was determined that the level of trust in a project is influenced by:

- the expectations that the project team have of each other;

- the knowledge exchange that takes place between them; and

- the degree of trust that is imported from other familiar settings (imported trust).

The degree of risk present in the project was found to have no significant link with the level of trust experienced in the project. This alters the widely accepted view that the relationship between risk and trust is reciprocal and contradicting the results published by Daim et al. (2012) which contended that an acceptable degree of risk is responsible for an increase in the level of trust in a project.

This study similarly found that the degree of collaboration in a project is influenced by:

- the physical proximity between its team members;

- the commitment the team members have towards the project;

- conflict between the team members where less conflict improves the collaboration;

- the degree of coordination in the project team;

- the strength of the relationships between team members and other stakeholders; and

- a balance of intrinsic and extrinsic incentives.

The overall review of the key findings has provided an interesting insight into the main "human-related" success factors in projects. However, a case study-based analysis on a number of successful and failed projects where the focus is on the extent of trust and collaboration in the project may further validate the findings from a practical perspective. The contrast between the successful and failed projects will be an important determination to highlight any distinctions between the factors impacting on success. Similar research conducted elsewhere with a large sample size would be more appropriate for realistic estimations of impacts and accuracy of results asserted in SEM analysis. Further research is currently being undertaken by the authors to model the relation between quality of communication and the other constructs.
Trust and collaboration in project teams 
IJMPB

11,2

\section{References}

Aapaoja, A., Herrala, M., Pekuri, A. and Haapasalo, H. (2013), "The characteristics of and cornerstones for creating integrated teams", International Journal of Managing Projects in Business, Vol. 6 No. 4, pp. 695-713.

Aga, D.A., Noorderhaven, N. and Vallejo, B. (2016), "Transformational leadership and project success: the mediating role of team-building", International Journal of Project Management, Vol. 34 No. 5 , pp. 806-818, doi: 10.1016/j.jproman.2016.02.012.

Agarwal, N. and Rathod, U. (2006), "Defining success for software projects: an exploratory revelation", International Journal of Project Management, Vol. 24 No. 4, pp. 358-370.

Ahola, T. (2009), "Efficiency in project networks: the role of inter-organizational relationships in project implementation”, Helsinki University of Technology.

Andersen, E.S., Birchall, D., Jessen, S.A. and Money, A.H. (2006), "Exploring project success”, Baltic Journal of Management, Vol. 1 No. 2, pp. 127-147, doi: 10.1108/17465260610663854.

Arbuckle, J.L. (2008), Amos 17.0 User's Guide, Amos Development Corporation, Crawfordville, FL.

Artto, K., Eloranta, K. and Kujala, J. (2008), "Subcontractors' business relationships as risk sources in project networks", International Journal of Managing Projects in Business, Vol. 1, pp. 88-105.

Atkinson, R. (1999), "Project management: cost, time and quality, two best guesses and a phenomenon, its time to accept other success criteria?", International Journal of Project Management, Vol. 17 No. 6, pp. 337-342.

AXELOS (2009), Managing Successful Projects with PRINCE2 ${ }^{\circledR}$, 5th ed., The Stationery Office, London.

Bedwell, W.L., Wildman, J.L., DiazGranados, D., Salazar, M., Kramer, W.S. and Salas, E. (2012), "Collaboration at work: an integrative multilevel conceptualization", Human Resource Management Review, Vol. 22 No. 2, pp. 128-145.

Belassi, W. and Tukel, O. (1996), "A new framework for determining critical success/failure factors in projects", International Journal of Project Management, Vol. 14 No. 3, pp. 141-151, doi: 10.1016/ 0263-7863(95)00064-X.

Belout, A. and Gauvreau, C. (2004), "Factors influencing project success: the impact of human resource management", International Journal of Project Management, Vol. 22 No. 1, pp. 1-11.

Bentler, P.M. (1990), "Comparative fit indexes in structural models", Psychological Bulletin, Vol. 107 No. 2, pp. 238-246.

Berssaneti, F.T. and Carvalho, M.M. (2015), "Identification of variables that impact project success in Brazilian companies", International Journal of Project Management, Vol. 33 No. 3, pp. 638-649, doi: 10.1016/j.ijproman.2014.07.002.

Bond-Barnard, T.J., Steyn, H. and Fletcher, L. (2014), "The specification of a structural equation (SEM) model for project communication, trust, collaboration and success", 28th IPMA World Congress, Elsevier International of Rotterdam, pp. 1-15.

Brady, T. (2004), "Building project capabilities: from exploratory to exploitative learning", Organization Studies, Vol. 25 No. 9, pp. 1601-1621, doi: 10.1177/0170840604048002.

Bresnen, M. (2007), "Deconstructing partnering in project-based organisation: seven pillars, seven paradoxes and seven deadly sins", International Journal of Project Management, Vol. 25 No. 4, pp. 365-374, doi: 10.1016/j.jproman.2007.01.007.

Bresnen, M. and Marshall, N. (2000), "Partnering in construction: a critical review of issues, problems and dilemmas", Construction Management and Economics, Vol. 18 No. 2, pp. 229-237.

Buvik, M. and Tvedt, S.D. (2017), "The influence of project commitment and team commitment on the relationship between trust and knowledge sharing in project teams", Project Management Journal, Vol. 48 No. 2, pp. 5-21.

Buvik, M.P. and Rolfsen, M. (2015), "Prior ties and trust development in project teams - a case study from the construction industry", International Journal of Project Management, Vol. 33 No. 7 , pp. 1484-1494, doi: 10.1016/j.ijproman.2015.06.002. 
Byrne, B.M. (2010), Structural Equation Modeling with AMOS: Basic Concepts, Applications and Programming, Multivariate Applications Series, Routledge/Taylor \& Francis Group, New York, NY.

Cambridge University Press (2017), "Knowledge integration", Cambridge Dictionary, available at: http://dictionary.cambridge.org/dictionary/business-english/knowledge-integration (accessed 3 August 2017).

Carvalho, M.M. (2008), “Communication issues in projects management”, PICMET, Cape Town, pp. 27-31.

Chang, T.-J. and Yeh, S.P. (2014), "Intra project team disagreement, conflict communications, and team performance in cross-functional new product project teams: a decision-making quality perspective", South African Journal of Economic and Management Sciences, Vol. 17 No. 1, pp. 91-104.

Chen, D.-N., Liang, T.-P. and Lin, B. (2010), "An ecological model for organizational knowledge management", Journal of Computer Information Systems, Vol. 50 No. 3, pp. 11-22.

Chiocchio, F., Forgues, D., Paradis, D. and Iordanova, I. (2011a), "Teamwork in integrated design projects: understanding the effects of trust, conflict, and collaboration on performance", IRNOP, Montreal, pp. 1-26.

Chiocchio, F., Forgues, D., Paradis, D. and Iordanova, I. (2011b), "The art of managing relationships in interorganizational collaboration", Project Management Journal, Vol. 42 No. 6, pp. 78-91, doi: $10.1002 / \mathrm{pmj}$.

Cicmil, S. and Marshall, D. (2005), "Insights into collaboration at the project level: complexity, social interaction and procurement mechanisms", Building Research and Information, Vol. 33 No. 6 , pp. 523-535, doi: 10.1080/09613210500288886.

Cohen, S.G. and Bailey, D.E. (1997), "What makes teams work: group effectiveness research from the shop floor to the executive suite", Journal of Management, Vol. 23 No. 3, pp. 239-290.

Cooke-davies, T. (2002), "The 'real' success factors on projects", International Journal of Project Management, Vol. 20 No. 3, pp. 185-190.

Daim, T.U., Ha, A., Reutiman, S., Hughes, B., Pathak, U., Bynum, W. and Bhatla, A. (2012), "Exploring the communication breakdown in global virtual teams", International Journal of Project Management, Vol. 30 No. 2, pp. 199-212.

Dalcher, D. and Societies, I. (2009), "Software project success: moving beyond failure”, Upgrade, CEPIS Journal, Vol. X No. 5, pp. 42-50.

Daspit, J., Tillman, C.J., Boud, N.G. and Mckee, V. (2013), "Cross-functional team effectiveness: an examination of internal team environment, shared leadership, and cohesion influences", Team Performance Management, Vol. 19.

Davies, A., Dodgson, M. and Gann, D. (2016), "Dynamic capabilities in complex projects: the case of london heathrow terminal 5", Project Management Journal, Vol. 47 No. 2, pp. 26-46.

de Carvalho, M.M., Patah, L.A. and de Souza Bido, D. (2015), "Project management and its effects on project success: cross-country and cross-industry comparisons", International Journal of Project Management, Vol. 33 No. 7, pp. 1509-1522, doi: 10.1016/j.jproman.2015.04.004.

De Dreu, C.K.W. and Weingart, L.R. (2003), "Task versus relationship conflict, team performance, and team member satisfaction: a meta-analysis", Journal of Applied Psychology, Vol. 88 No. 4, pp. 741-749, doi: 10.1037/0021-9010.88.4.741.

De Wit, A. (1988), "Measurement of project success", International Journal of Project Management, Vol. 6 No. 3, pp. 164-170.

Diallo, A. and Thuillier, D. (2005), "The success of international development projects, trust and communication: an African perspective”, International Journal of Project Management, Vol. 23 No. 3, pp. 237-252, doi: 10.1016/j.ijproman.2004.10.002.

Dietrich, P., Economics, B., Eskerod, P., Dalcher, D. and Sandhawalia, B. (2010), "The role of project collaboration quality and knowledge integration capability in multipartner projects", PMI Research \& Education Conference, PA, pp. 1-38 
IJMPB

11,2

Dietz, G. and Hartog, D.N.D (2006), "Measuring trust inside organisations", Personnel Review, Vol. 35 No. 5, pp. 557-588, doi: 10.1108/00483480610682299.

Doloi, H., Iyer, K.C. and Sawhney, A. (2011), "Structural equation model for assessing impacts of contractor's performance on project success", International Journal of Project, Vol. 29 No. 6, pp. 687-695, doi: 10.1016/j.ijproman.2010.05.007.

Dubois, A. and Gadde, L.-E. (2000), "Supply strategy and network effects - purchasing behaviour in the construction industry", European Journal of Purchasing \& Supply Management, Vol. 6 Nos 3-4, pp. 207-215.

Dwivedula, R., Bredillet, C.N. and Müller, R. (2016), "Personality and work motivation as determinants of project success: the mediating role of organisational and professional commitment", International Journal of Management Development, Vol. 1 No. 3, pp. 229-245.

Eloranta, K. (2007), "Supplier relations management in networked project business", Helsinki University of Technology.

Errasti, A., Beach, R., Oyarbide, A. and Santos, J. (2007), "A process for developing partnerships with subcontractors in the construction industry: an empirical study", International Journal of Project Management, Vol. 25 No. 3, pp. 250-256.

Faerman, S.R., Mccaffrey, D.P. and van Slyke, D.M. (2001), "Understanding interorganisational cooperation: public-private collaboration in regulating financial market innovation", Organization Science, Vol. 12 No. 3, pp. 372-388.

Farris, G.F. and Cordero, R. (2002), "Leading your scientists and engineers 2002”, Research Technology Management, Vol. 45 No. 6, pp. 13-25.

Fortune, J. and White, D. (2006), "Framing of project critical success factors by a systems model", International Journal of Project Management, Vol. 24 No. 1, pp. 53-65.

Fox, S. (2001), "Effective communication: stone age to e-comm", PMI Annual Seminars and Symposium, Project Management Institute, Nashville, TN.

Gil, N., Pinto, J.K. and Smyth, H. (2011), "Trust in relational contracting and as a critical organizational attribute", in Morris, P.W.G., Pinto, J., and Söderlund, J. (Eds), The Oxford Handbook of Project Management, Oxford University Press, Oxford, pp. 438-460.

Grabher, G. (2002), "Cool projects, boring institutions: temporary collaboration in social context", Regional Studies, Vol. 36 No. 3, pp. 205-214, doi: 10.1080/00343400220122025.

Handy, C. (1995), "Managing the dream", in Chawla, S. and Renesch, J (Eds), Learning Organisations: Developing Cultures for Tomorrow's Workplace, Productivity Press, Portland, OR, pp. 45-56.

Henderson, L.S., Stackman, R.W. and Lindekilde, R. (2016), "The centrality of communication norm alignment, role clarity, and trust in global project teams", International Journal of Project Management, Vol. 34 No. 8, pp. 1717-1730, doi: 10.1016/j.ijproman.2016.09.012.

Herscovitch, L. and Meyer, J.P. (2002), "Commitment to organizational change: extension of a threecomponent model”, Journal of Applied Psychology, Vol. 87 No. 3, pp. 474-487, doi: 10.1037/00219010.87.3.474.

Hoegl, M. and Gemuenden, H.G. (2001), "Teamwork quality and the success of innovative projects: a theoretical concept and empirical evidence", Organization Science, Vol. 12 No. 4, pp. 435-449.

Hoegl, M., Weinkauf, K. and Gemuenden, H.G. (2004), "Interteam coordination, project commitment, and teamwork in multiteam R\&D projects: a longitudinal study", Organization Science, Vol. 15 No. 1, pp. 38-55.

Holton, J.A. (2001), "Building trust and collaboration in a virtual team", International Journal of Team Performance Management, Vol. 7 No. 3, pp. 36-47.

Ibrahim, C.K.I.C., Costello, S.B. and Wilkinson, S. (2015), "Key indicators influencing the management of team integration in construction projects", International Journal of Managing Projects in Business, Vol. 8 No. 2, pp. 300-323. 
Ika, L.A., Diallo, A. and Thuillier, D. (2011), "Critical success factors for World Bank projects: an empirical investigation", International Journal of Project Management, Vol. 30 No. 1, pp. 105-116, doi: 10.1016/j.jproman.2011.03.005.

Ingram, P. and Baum, J.A.C. (2001), "Interorganizational learning and the dynamics of chain relationships", in Baum, J.A.C. and Greve, H.R. (Eds), Multiunit Organization and Multimarket Strategy, Emerald Group Publishing Limited, Stamford, CT, pp. 109-139.

Jap, S.D. (1999), "Efforts: processes in collaboration buyer-supplier relationships", Journal of Marketing Research, Vol. 36 No. 4, pp. 461-475.

Jarvenpaa, S.L. and Leidner, D. (1998), "Communication and trust in global virtual teams", Journal of Computer-Mediated Communication, Vol. 3.

Jugdev, K. and Müller, R. (2005), "A retrospective look at our evolving understanding of project success", Project Management Journal, Vol. 36 No. 4, pp. 3-19.

Kadefors, A. (2004), "Trust in project relationships - inside the black box", International Journal of Project Management, Vol. 22 No. 3, pp. 175-182, doi: 10.1016/S0263-7863(03)00031-0.

Kahn, K.B. and McDonough, E.F.I. (1997), "An emperical study of the relationships among co-location, integration, performance and satisfaction”, Journal of Product Innovation Management, Vol. 14 No. 3, pp. 161-178.

Kalkman, J.P. and de Waard, E.J. (2017), "Inter-organizational disaster management projects: finding the middle way between trust and control", International Journal of Project Management, Vol. 35 No. 5, pp. 889-899, doi: 10.1016/j.ijproman.2016.09.013.

Kendra, K. and Taplin, L.J. (2004), "Project success: a cultural framework", Project Management Journal, Vol. 35, pp. 30-45.

Klimkeit, D. (2013), "Organizational context and collaboration on international projects: the case of a professional service firm", International Journal of Project Management, Vol. 31 No. 3, pp. 366-377.

Kline, R.B. (2010), Principles and Practice of Structural Equation Modeling, 3rd ed., The Guilford Press, New York, NY.

Koelmans, R.G. (2004), "Project success and performance evaluation”, International Platinum Conference 'Platinum Adding Value' The South African Institute of Mining and Metallurgy, pp. 229-236.

Kozlowski, S.J. and Bell, B.S. (2003), "Work groups and teams in organizations", in Borman, W.C., Ilgen, D.R., Klimoski, R.J. and Weiner, I.B. (Eds), Handbook of Psychology: Industrial and Organizational Psychology, Wiley, London, pp. 333-375, available at: https://doi.org/DOI:10. 1002/0471264385.wei1214

Ksenija, Č. and Skendrovic, V. (2010), "Communication management is critical for project success", Informatol, Vol. 43 No. 3, pp. 228-235.

LePine, J.A., Piccolo, R.F., Jackson, C.L., Mathieu, J.E. and Saul, J.R. (2008), "A meta-analysis of teamwork processes: tests of a multidimensional model and relationships with team effectiveness criteria", Personnel Psychology, Vol. 61 No. 2, pp. 273-307, doi: 10.1111/j.1744-6570.2008.00114.x.

Lesko, C.J. and Hollingsworth, Y.A. (2010), "Integration of 3D web and semantic web technologies: a new structure for communications plans", PMI Research and Education Conference, Project Management Institute, pp. 1-19.

Levesque, P. (2005), "Definition of knowledge exchange and knowledge mobilization", Knowledge Mobilization Work, available at: http://knowledgemobilizationworks.blogspot.com/2005/11/ definition-of-knowledge-exchange-and.html

Lin, C.C.T. and Peng, T.K.T. (2010), "From organizational citizenship behaviour to team performance: the mediation of group cohesion and collective efficacy", Management Organization Review, Vol. 6 No. 1, pp. 55-75.

McDermott, P., Khalfan, M. and Swan, W. (2004), "An exploration of the relationship between trust and collaborative working in the construction sector", Construction Information Quarterly, Vol. 6 No. 4, pp. 140-146. 
IJMPB

11,2

Manu, E., Ankrah, N., Chinyio, E. and Proverbs, D. (2015), "Trust influencing factors in main contractor and subcontractor relationships during projects", International Journal of Project Management, Vol. 33 No. 7, pp. 1495-1508, doi: 10.1016/j.ijproman.2015.06.006.

Martens, M.L. and Carvalho, M.M. (2016), "The challenge of introducing sustainability into project management function: multiple-case studies", Journal of Cleaner Production, Vol. 117, pp. 29-40, doi: 10.1016/j.jclepro.2015.12.039.

Martín-Rodríguez, L.S., Beaulieu, M.-D., D’Amour, D. and Ferrada-Videla, M. (2005), “The determinants of successful collaboration: a review of theoretical and empirical studies", Journal of Interprofessional Care, Vol. 19 No. S1, pp. 132-147, doi: 10.1080/13561820500082677.

Marzagao, D.S.L. and Carvalho, M.M. (2016), "Critical success factors for six sigma projects", International Journal of Project Management, Vol. 34 No. 8, pp. 1505-1518, doi: 10.1016/j. ijproman.2016.08.005.

Maylor, H. (2003), Project Management, 3rd ed., Pearson Education Limited, Essex.

Meyerson, D., Weick, K.E. and Kramer, R.M. (1996), "Swift trust and temporary groups", in Kramer, M. and Tyler, T.R. (Eds), Trust in Organizations: Frontiers of Theory and Research, Sage Publications, Thousand Oaks, CA, pp. 166-195.

Mir, F.A. and Pinnington, A.H. (2014), "Exploring the value of project management: linking project management performance and project success", International Journal of Project Management, Vol. 32 No. 2, pp. 202-217, doi: 10.1016/j.ijproman.2013.05.012.

Mishra, A., Chandrasekaran, A. and Maccormack, A. (2015), "Collaboration in multi-partner R\&D projects: the impact of partnering scale and scope", Journal of Operations Management, Vol. 33-34, pp. 1-14, doi: 10.1016/j.jom.2014.09.008.

Mohr, J. and Spekman, R. (1994), "Characteristics of partnership success: partnership attributes, communication behavior, and conflict resolution techniques", Strategic Management Journal, Vol. 15 No. 2, pp. 135-152, doi: 10.1002/smj.4250150205.

Molenaar, K., Washington, S. and Diekmann, J. (2000), "Structural equation model of contruction contract dispute potential", Journal of Construction Engineering and Management, Vol. 126 No. 4, pp. 268-277.

Moodysson, J. and Jonsson, O. (2007), "Knowledge collaboration and proximity: the spatial organization of biotech innovation projects", European Urban and Regional Studies, Vol. 14 No. 2, pp. 115-131, doi: 10.1177/0969776407075556.

Müller, R. (2003), "Determinants for external communications of IT project managers", International Journal of Project Management, Vol. 21 No. 5, pp. 345-354, doi: 10.1016/S0263-7863(02)00053-4.

Mumbi, C. and McGill, T. (2008), "An investigation of the role of trust in virtual project management success", International Journal of Networking and Virtual Organisations, Vol. 5 No. 1, pp. 64-82.

Mumbi, C.K. (2007), "An investigation of the role of trust in virtual project management success", Murdoch University.

Munns, A.K. (1995), "Potential influence of trust on the successful completion of a project", International Journal of Project Management, Vol. 13 No. 1, pp. 19-24, doi: 10.1016/0263-7863(95) 95699-E.

Ochieng, E.G. and Price, A.D.F. (2010), "Managing cross-cultural communication in multicultural construction project teams: the case of Kenya and UK", International Journal of Project Management, Vol. 28 No. 5, pp. 449-460, doi: 10.1016/j.ijproman.2009.08.001.

O'Leary-Kelly, A.M., Martocchio, J.J. and Frink, D.D. (1994), “A review of the influence of group goals on group performance”, The Academy of Management Journal, Vol. 37 No. 5, pp. 1285-1301.

O’Neill, T.A., Allen, N.J. and Hastings, S.E. (2013), "Examining the 'pros' and 'cons' of team conflict: a team-level meta-analysis of task, relationship, and process conflict", Human Performance, Vol. 26 No. 3, pp. 236-260.

Oxford University Press (2017), "English oxford living dictionaries", available at: https://en.ox forddictionaries.com (accessed 3 August 2017). 
Pinto, J. and Slevin, D. (1988), "Critical success factors across the project life cycle", Project Management Journal, Vol. 19 No. 3, pp. 67-75.

Pinto, J.K., Slevin, D.P. and English, B. (2009), "Trust in projects: an empirical assessment of owner/contractor relationships", International Journal of Project Management, Vol. 27 No. 6, pp. 638-648, doi: 10.1016/j.ijproman.2008.09.010.

Pinto, M.B., Pinto, J.K. and Prescott, J.E. (1993), “Antecedents and team consequences of project cooperation", Management Science, Vol. 39 No. 10, pp. 1281-1297.

PMI (2017), A Guide to the Project Management Body of Knowledge, 6thd ed., Project Management Institute, Inc., Newton Square, PA.

Porter, T. and Lilly, B. (1996), "The effects of conflict, trust, and task commitment on project team performance", International Journal of Conflict Management, Vol. 7 No. 4, pp. 361-376.

Rezvani, A., Chang, A., Wiewiora, A., Ashkanasy, N.M., Jordan, P.J. and Zolin, R. (2016), "Manager emotional intelligence and project success: the mediating role of job satisfaction and trust", International Journal of Project Management, Vol. 34, pp. 1112-1122, available at: https://doi.org/ 10.1016/j.jproman.2016.05.012

Rounce, G. (1998), "Quality, waste and cost considerations in architectural building design management", International Journal of Project Management, Vol. 16 No. 2, pp. 123-127, doi: 10.1016/S0263-7863(97)00042-2.

Rousseau, D.M., Sitkin, S.B., Burt, R.S. and Camerer, C. (1998), "Not so different after all: a cross-discipline view of trust", Academy of Management Review, Vol. 23 No. 3, pp. 393-404.

Scott-Young, C. and Samson, D. (2008), "Project success and project team management: evidence from capital projects in the process industries", Journal of Operations Management, Vol. 26 No. 6 , pp. 749-766.

Shenhar, A.J. and Dvir, D. (2007), Reinventing Project Management, Harvard Business School Press, Boston, MA.

Silén-Lipponen, M., Turunen, H. and Tossavainen, K. (2002), "Collaboration in the operating room: the nurses' perspective”, Journal of Nursing Administration, Vol. 32 No. 1, pp. 16-19.

Skaatesa, M.A. and Tikkanen, H. (2003), "International project marketing: an introduction to the INPM approach", International Journal of Project Management, Vol. 21 No. 7, pp. 503-510.

Smyth, H., Gustafsson, M. and Ganskau, E. (2010), "The value of trust in project business", International Journal of Project Management, Vol. 28 No. 2, pp. 117-129, doi: 10.1016/j. ijproman.2009.11.007.

Stawnicza, O. and Kurbel, K. (2012), "How to prevent before you must cure - a comprehensive literature review on conflict management strategies in global project teams", 7th International Research Workshop on IT Project Management, Orlando, FL.

Swan, W., McDermott, P., Wood, G., Thomas, A. and Abott, C. (2002), Trust in Construction: Achieving Cultural Change, Centre for Construction Innovation, Manchester.

The Standish Group International (2009), “CHAOS summary 2009”, available at: www.standishgroup. com/ (accessed 12 December 2016).

Tjosvold, D., Hui, C., Ding, D.Z. and Hu, J. (2003), "Conflict values and team relationships: conflict's contribution to team effectiveness and citizenship in China", Journal of Organizational Behavior, Vol. 24 No. 1, pp. 69-88.

Todorović, M.L., Petrović, D.Č., Mihić, M.M., Obradović, V.L. and Bushuyev, S.D. (2015), "Project success analysis framework: a knowledge-based approach in project management", International Journal of Project Management, Vol. 33 No. 4, pp. 772-783, doi: 10.1016/j.jproman.2014.10.009.

Tucker, L.R. and Lewis, C. (1973), "A reliability coefficient for maximum likelihood factor analysis", Psychometrika, Vol. 38 No. 1, pp. 1-10.

Turner, J.R. and Cochrane, R.A. (1993), "Goals-and-methods matrix: ill defined goals and/or methods of achieving them”, International Journal of Project Management, Vol. 11, pp. 93-102.
Trust and collaboration in project teams 
IJMPB

11,2

Turner, J.R. and Müller, R. (2004), "Communication and co-operation on projects between the project owner as principal and the project manager as agent", European Management Journal, Vol. 22 No. 3, pp. 327-336, doi: 10.1016/j.emj.2004.04.010.

Turner, J.R. and Müller, R. (2005), "The project manager's leadership style as a success factor on projects: a literature review", Project Management Journal, Vol. 36 No. 1, pp. 49-61.

Tyler, T.R. (2003), “Trust within organisations", Personnel Review, Vol. 32 No. 5, pp. 556-568, doi: $10.1108 / 00483480310488333$

Vaaland, T.I. (2004), "Improving project collaboration: start with the conflicts", International Journal of Project Management, Vol. 22 No. 6, pp. 447-454. doi: 10.1016/j.jproman.2003.11.003.

Vaaland, T.I. and Håkansson, H. (2003), "Exploring interorganizational conflict in complex projects", Industrial Marketing Management, Vol. 32 No. 2, pp. 127-138, doi: 10.1016/S0019-8501(02)00227-4.

Van den Bulte, C. and Moenaert, R.K. (1998), "The effects of R\&D team co-location on communication patterns among R\&D, marketing, and manufacturing”, Management Science, Vol. 44 No. 11, pp. 1-18.

Vandenberghe, C., Bentein, K. and Stinglhamber, F. (2004), "Affective commitment to the organization, supervisor, and work group: antecedents and outcomes", The Journal of Vocational Behavior, Vol. 64 No. 1, pp. 47-71.

Walker, D.H. and Lloyd-Walker, B.M. (2015), Collaborative Project Procurement Arrangements, Project Management Institute, Newtown Square, PA.

Web Finance Inc (2017), "Innovation”, Business Dictionary, available at: www.businessdictionary.com/ definition/innovation.html (accessed 3 August 2017).

Webber, S.S. (2008), "Blending service provider - client project teams to achieve client trust: implication for project team trust, cohesion, and performance", Project Management Journal, Vol. 39 No. 2, pp. $72-81$.

Weiping, J., Lu, Y. and Le, Y. (2016), "Trust and project success: a twofold perspective between owners and contractors", Journal of Management in Engineering, Vol. 32 No. 6, p. 04016022.

West, S.G., Finch, J.F. and Curran, P.J. (1995), "Structural equation models with nonnormal variables: problems and remedies", in Hoyle, R.H. (Ed.), Structural Equation Modeling: Concepts, Issues and Applications, Sage Publications, Thousand Oaks, CA, pp. 56-75.

Westerveld, E. (2003), "The project excellence model ${ }^{\circledR}$ : linking success criteria and critical success factors", International Journal of Project Management, Vol. 21 No. 6, pp. 411-418, doi: 10.1016/S0263-7863(02)00112-6.

White, D. and Fortune, J. (2002), "Current practice in project management-an empirical study", International Journal of Project Management, Vol. 20, pp. 1-11.

Wong, P.S.P. and Cheung, S.O. (2005), "Structural equation model of trust and partnering success", Journal of Management in Engineering, Vol. 21 No. 1, pp. 70-80, doi: 10.1061/(ASCE)0742-597X (2005)21.

Yalegama, S., Chileshe, N. and Ma, T. (2016), "Critical success factors for community-driven development projects: a Sri Lankan community perspective", International Journal of Project Management, Vol. 34, pp. 643-659, available at: https://doi.org/10.1016/j.jproman.2016.02.006

Yang, J. (2005), "Knowledge integration and innovation: securing new product advantage in high technology industry", Journal of High Technology Management Research, Vol. 16 No. 1, pp. 121-135, doi: 10.1016/j.hitech.2005.06.007.

Yung, Y.-F. and Bentler, P.M. (1996), "Bootstrap-corrected ADF test statistics in covariance structure analysis", in Marcoulides, G.A. and Schumacker, R.E. (Eds), Advanced Structural Equation Modeling: Issues and Techniques, Lawrence Erlbaum Associates, Mahwah, NJ, pp. 195-226.

Zhu, W. (1997), "Making bootstrap statistical inferences: a tutorial", Research Quarterly for Exercise and Sport, Vol. 68 No. 1, pp. 44-55. 


\section{Further reading}

Wong, W.K., Cheung, S.O., Yiu, T.W. and Pang, H.Y. (2008), "A framework for trust in construction contracting", International Journal of Project Management, Vol. 26 No. 8, pp. 821-829, doi: 10.1016/j.ijproman.2007.11.004.
Trust and collaboration in project teams

\section{Appendix}

\begin{tabular}{lll} 
Question & Model & \\
No. & variable input Question & Scale \\
\hline
\end{tabular}

Project trust

Please think about your experience of working Text

with other project team members in a typical

project, before answering the following questions

Q18_2 Expectations To what extent is the project communication that Extent on a scale of 1 (to an you receive predictable (e.g. from the expected extremely small extent) to 10 sender, in the accepted format, with the (to an extremely large extent) appropriate content)? (matrix table, single answer)

Q18_3 Expectations To what extent do you receive communication Extent on a scale of 1 (to an regarding the project on time/when you require it? extremely small extent) to 10 (matrix table, single answer)

(to an extremely large extent)

Q19_1 Knowledge To what extent do you receive project knowledge Extent on a scale of 1 (to an exchange from others during project communication opportunities? (matrix table, single answer) extremely small extent) to 10 (to an extremely large extent)

Q19_2 Knowledge To what extent do you convey your knowledge to exchange others during project communication opportunities? (matrix table, single answer)

Extent on a scale of 1 (to an extremely small extent) to 10 (to an extremely large extent)

Project collaboration

Q22_1 Commitment To what extent are you committed to achieving the project goals? (Likert, single answer)

Q22_2 Commitment To what extent are the other team members

Extent on a scale of 1 (to an extremely small extent) to 10 (to an extremely large extent) Extent on a scale of 1 (to an committed to achieving the project goals? (Likert, extremely small extent) to 10 single answer)

Q24_1 Coordination To what extent is your understanding of the (to an extremely large extent) project goals aligned with that of your other team members? (matrix table, single answer)

Extent on a scale of 1 (to an

extremely small extent) to 10 (to an extremely large extent)

Q24_2 Coordination To what extent are you aware of the project rules and procedures? (matrix table, single answer)

Extent on a scale of 1 (to an extremely small extent) to 10 (to an extremely large extent)

Q24_3 Coordination To what extent does everyone in the project team Extent on a scale of 1 (to an have a shared/the same understanding of the project goals? (matrix table, single answer)

Q24_4 Coordination To what extent is the project team's actions/work coordinated? (i.e. working together with a shared understanding of mutual goals) extremely small extent) to 10 (to an extremely large extent) Extent on a scale of 1 (to an extremely small extent) to 10 (to an extremely large extent)

Table AI.

Excerpt of questionnaire

\section{Corresponding author}

Taryn Jane Bond-Barnard can be contacted at: taryn.barnard@up.ac.za

For instructions on how to order reprints of this article, please visit our website:

www.emeraldgrouppublishing.com/licensing/reprints.htm

Or contact us for further details: permissions@emeraldinsight.com 